Vol. 2, No. 1, 2020

https://doi.org/10.23939/jtbp2020.01.046

Orest Voznyak, Yurij Yurkevych, Mariana Kasynets, Iryna Sukholova, Oleksandr Dovbush

\title{
THE CONTACT-SURFACE HEAT UTILIZER
}

\author{
Department of Heat and Gas Supply and Ventilation, \\ Lviv PolytechnicNational University \\ orest.voznyak@i.ua
}

(C) Voznyak O., Yurkevych Yu., Kasynets M., Sukholova I., Dovbush O., 2020

In industry contact-surface heat exchangers are used. Deep chilling of burning products is realised in these apparatuses $\left(30-40{ }^{\circ} \mathrm{C}\right)$. At calculation of contact-surface heat exchangers the transfer coefficient of full heat for nozzle chamber $\sigma$ against of determinative factors both for contact part and for irrigated surface heat exchangeris the most important. It may be obtained by several methods. By this there is difficulty at choice of the most effective method, which would provide high accuracy of this value calculation and also would not be too complicated.

The aim of this article is choice of the most rational schemes of heat utilization equipment composition for the endogas burning products heat utilization and design of engineering method of this equipment calculation. The dependencies obtained are quite simple, easy to use and give good consistency of the results. An effective method of determination of the full heat transfer coefficient for nozzle chamber in contact heat exchangers at any given output values at the specified interval, which makes it possible to conduct calculations both graphically and analytically, is proposed. In this article there is proposed method of value $\sigma$ calculation for contact-surface heat exchangers, which corresponds both conditions described above. Method of numeral integration is chosen as a base. It allows to calculate an value $\sigma$ with the highest accuracy. Value $\sigma i s$ presented as function against $\mathbf{4}$ independent arguments. Obtained results are presented as a chart, which is approximated by an equation. Thus, we assert that effective method for calculation of the transfer coefficient of full heat for nozzle chamber in contact-surface heat exchangers, which are used for common and technological hot-water supply, is composed.

Key words: contact-surface heat utilizer, endogas, ceramic Rashig tubes, active nozzle chamber, full heat transfer coefficient, irrigated surface, heat exchanger.

\section{Introduction}

At chemical-heat treatment of metal products as protective medium is widely applied endogas, which is result of partial burning and conversion of natural gas. The spent endogas can be regarded as a source of low-potential burning secondary source of energy (SSE) (Aronov, 1978; Sosnin, 1974). Its specific heat of burning is $Q_{H}^{p}=6650 \mathrm{~kJ} / \mathrm{m}^{3}$.

It is advisable to use a surface-to-surface utilizer to use the heat of endogas combustion products. It is one of the means of achieving energy savings (Mysak et al., 2014; Zhelykh et al., 2009; Voznyak et al., 2017; Voznyak et al., 2005; Varlamov et al., 2016). Its efficiency depends on the lay out of the contact chamber and the nature of the hot water consumers.

\section{Target of this article}

This article is intended for choice of the most rational schemes of heat utilization equipment composition for the endogas burning products heat utilization and design of engineering method of this equipment calculation.

\section{Techniques used}

There were carried out experimental investigation of contact-surface heat utilizer, in which contact nozzle chamber and intermediate surface heat exchanger is applied. 
There are regarded four schemes of composition (Fig. 1) of heat-accepting part of heat-utilization apparatuses (HUA). In the first - scheme A, HUA was made as contact chamber (Aronov, 1978) of a type with is equipped of the inserted ceramic Rashig tubes (50x50x5). In the second one - scheme B, nozzle contact heat utilizer extra equipped by intermediate surface heat exchanger (Sosnin, 1974).In two next versions it have been investigated HUA with contact chamber of combined type, which consists of nozzle chamber and irrigated surface heat exchanger [3], moreover in the third scheme (scheme C) surface heat exchanger was situated as the first on a course of combustion gases, and in the fourth scheme (scheme D) - as the second. As carried out intermediate heat exchanger two sections fast-track water-heating apparatuses with the total area of heat $13 \mathrm{~m}^{2}$ were used. Height of nozzle chamber was varied in intervals $0,25-0,55 \mathrm{~m}$.
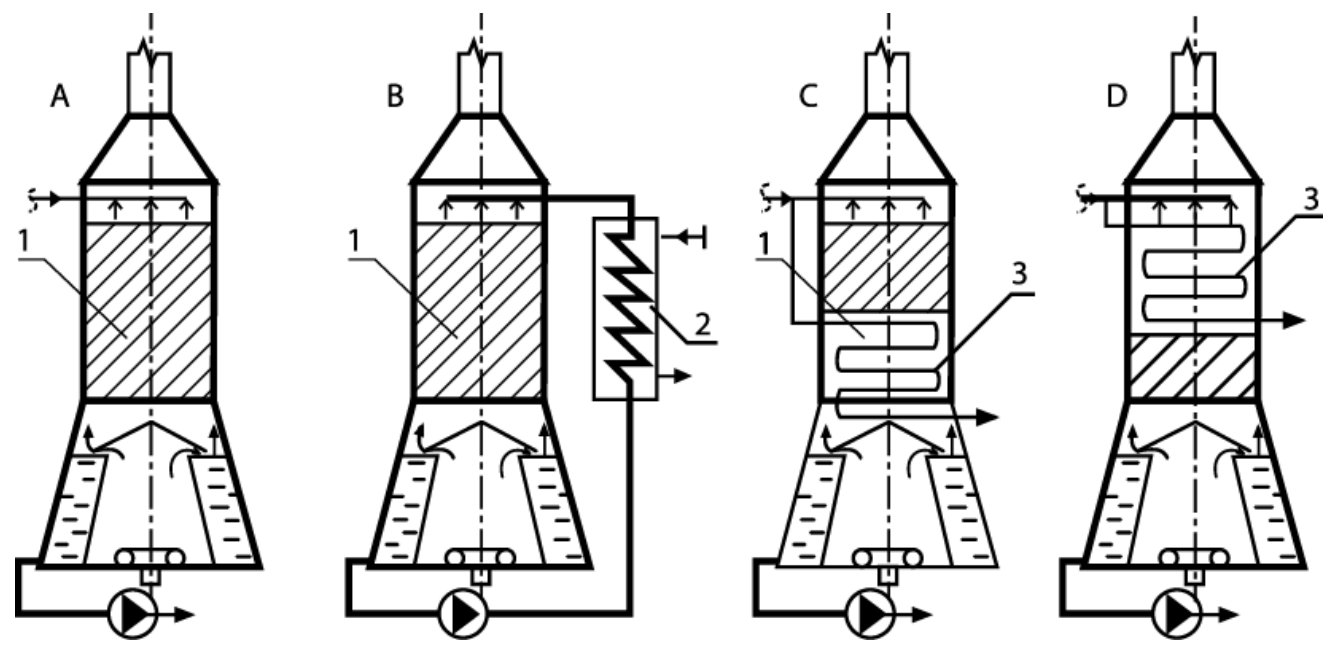

Fig. 1. Schemes of heat-utilizer composition

The research technique supposed measurement of all magnitudes, which one in an obvious or latent aspect go for an equation of a heat balance and allow to define a thermal output, indexes of efficiency and aerodynamic properties of the apparatuses.



Fig. 2. Chart for determination of a transfer coefficient of full heat for nozzle chamber 
On a base of obtained experimental data charts have been created for determination of a transfer coefficient of full heat for nozzle chamber oagainst of determinative factors both for contact part (Fig. 2) and for irrigated surface heat exchanger (Fig. 3).This data is obtained due to mathematic models (Voznyak et al., 2005; Salo \& Kucherenko, 2007; Kudinov, 2000).

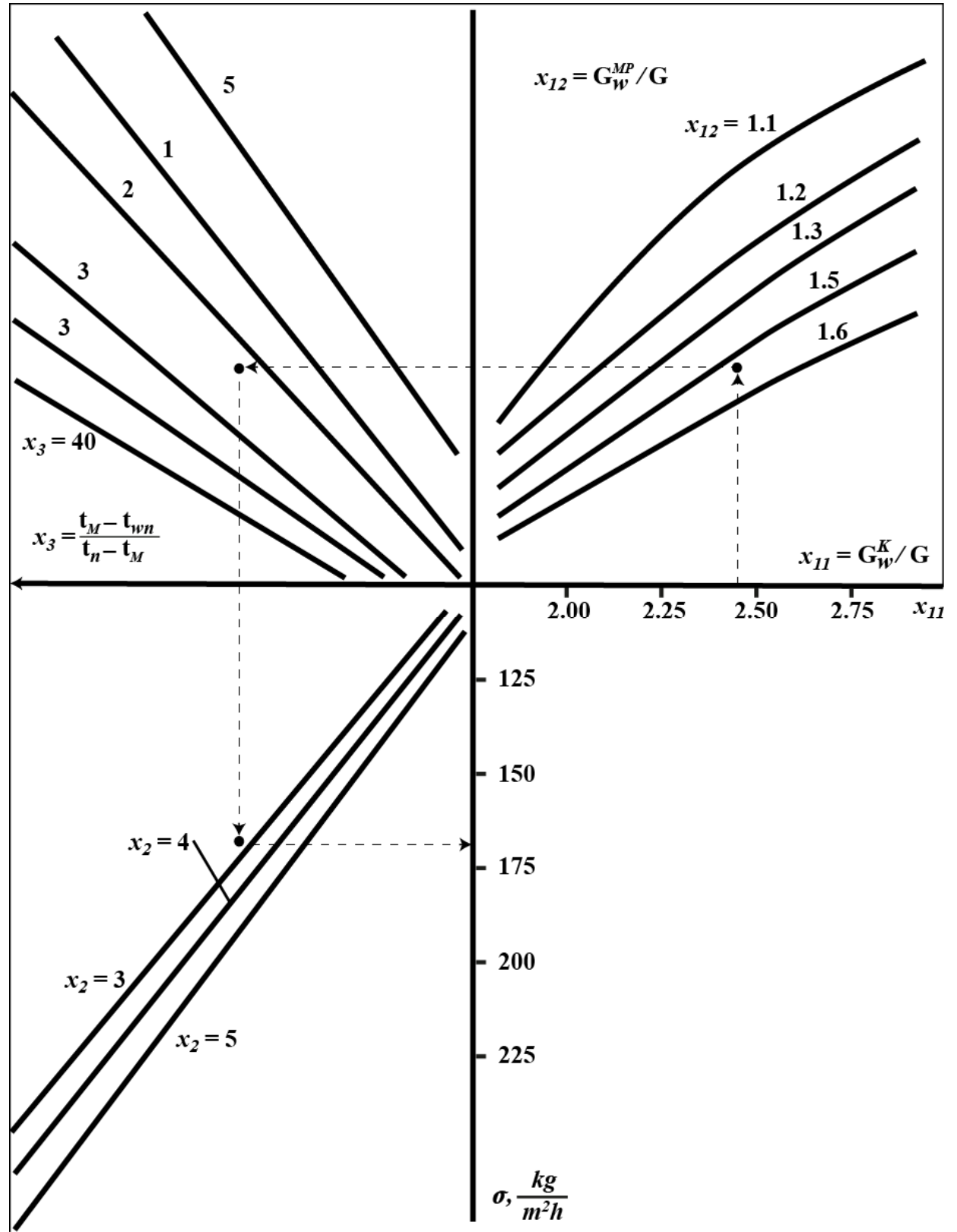

Fig. 3. Chart for determination of a transfer coefficient of full heat for irrigated surface heat exchanger (scheme D)

Both chart have been approximated due to personal computer. For nozzle chamber altitude $\sigma$ (Fig. 2) is calculated by equation:

$$
\sigma=-132.28+833.23 x_{3}+\left(59.11-111.0 x_{3}\right) \cdot\left(1.44-0.11 x_{2}\right) \cdot\left(x_{1}+1.35\right)
$$

For the irrigated surface heat exchanger (scheme D) altitude $\sigma$ (Fig. 3 ) is calculated:

$$
\begin{aligned}
\sigma= & 92+2 x_{2}+\left(0.64+0.09 x_{2}\right) \cdot\left(151.57-1.60 x_{3}+\left(23.47-0.29 x_{12} \times\right.\right. \\
& \left.\times\left(\left(7.81 x_{12}-19.41\right)+\left(13.96-6.11 x_{12}\right) \cdot x_{11}\right)\right)
\end{aligned}
$$


At the irrigated surface heat exchanger installation according scheme $\mathrm{C}$, as experimental investigations showed, determinative factors do not influence on transfer coefficient of full heat for nozzle chamber $\sigma$. For this scheme for total interval of factors varying altitude $\sigma$ is between $70-75 \mathrm{~kg} /\left(\mathrm{m}^{2} \cdot \mathrm{h}\right)$ (Ionkin et al., 2015; Izyumov \& Supranov, 2010).

Obtained empirical dependences for calculation heat output each of constructive scheme of heat utilizer composition (for schemes $\mathrm{C}$ and $\mathrm{D}$ - at irrigated surface heat exchanger with $n=4$ ).

Scheme A:

Scheme B:

$$
Q=7.98+1.15 \cdot\left[(v \rho)_{\text {жи }}-0.3\right]^{0,26}+5.88 H+5.78 \delta
$$

$$
Q=2.88+1.11 \cdot\left[(v \rho)_{\text {жи }}-0.3\right]^{0,23}+5.14 H+6.08 \delta
$$

Scheme C:

$$
Q=15.12+1.18 \cdot\left[(v \rho)_{\text {жn }}-0.3\right]^{0,30}+3.36 H+4.45 \delta
$$

Scheme D:

$$
Q=11.26+1.16 \cdot\left[(v \rho)_{\text {жn }}-0.3\right]^{0,28}+4.37 H+2.02 \delta
$$

With the purpose of matching efficiency any of the schemes of HUA composition main indexes of power efficiency of apparatuses have been determined. The estimation of a degree usage of a heat of endogas products combustion was realize due to usage waste energy coefficient $\left(\eta=Q / Q_{B E P}\right)$, thermal index of installation efficiency $\left(\eta_{m}=Q / Q_{\text {макс }}\right)$. Comparison of HUA composition schemes have been realized on the basis of exergy balance, that allowed to carry out an estimation of separated components from the point of view of extremely ability for work realization and to calculate exergy index efficiency (Mel'nikov et al., 2014; Pleshanov et al., 2014).

It must be noted, that estimation and comparison of the schemes of HUA composition efficiency is carried out due to exergy index efficiency, completely according with results obtained at calculation of energy efficiency indexes $\eta_{\mathrm{T}} \mathrm{i} \mathrm{E}_{\mathrm{i}}$. Analysis of results has showed, that the highest efficiency belongs to heat utilizer at the scheme of composition A. However this scheme is recommended only for providing with hot water technological consumers only. Efficiency of heat utilizer at scheme B is the lowest. But advantage of this scheme is fact that all heated water corresponds to health demands and can be applied for needs of common hot water supply. Intermediate place fill accordingly schemes of composition C and $\mathrm{D}$, that allow at the same time to provide with hot water both common and technological consumers. By this scheme $\mathrm{C}$ is recommended at relation $\mathrm{Q}^{\mathrm{h}} / \mathrm{Q}^{\mathrm{tec}}=0.20-0.35$, and scheme $\mathrm{D}-$ accordingly $0.15-0.25$.

\section{Conclusions}

1. The dependencies obtained are quite simple, easy to use and give good consistency of the results.

2. An effective method of determination of the transfer coefficient of full heat for nozzle chamber in contact heat exchangers at any given output values at the specified interval, which makes it possible to conduct calculations both graphically and analytically, is proposed.

\section{References} Russian).

Aronov, I. (1978). Contact water heating with burning products of natural gas. Leningrad: Nauka (in

Sosnin, J. (1974). Contact water heaters. Moscow: Strojizdat (in Russian).

Mysak, Y., Voznyak, O., Datsko, O., \& Shapoval, S. (2014). Solar energetic. Theory and practice. Lviv: NULP (in Ukrainian).

Zhelykh, V. M., Voznyak, O. T., \& Yurkevych, Yu. S. (2009). Unconventional energy sources. Lviv: NULP, (in Ukrainian).

Voznyak, O. T., Sukholova, I. Y., Savchenko, O. O., \& Dovbush, O. M. (2017). Thermal modernization of the air conditioning system of industrial premises, Proc. Of Odesa Construction and Architecture State University, No. $68,114-120$ (in Ukrainian). 
Voznyak, O. T., Myroniuk, K. V., \& Dovbush, O. M. (2005). Relationship between a person heat exchange and indoor climate, Proc. "Selected scientific Papers" of the $10^{\text {th }}$ Rzeszow-Lviv-Kosice Conference Supplementary Issue, Technical University of Kosice. 148-152.

Salo, V.P., \& Kucherenko, S.V. (2007). Use of condensation-type water heaters in decentralized heat supply schemes. COK 04/2007. Retrieved from http://www.c-o-k.com.ua/content/view/947/ (in Russian).

Varlamov, G., Romanova, K., Dashchenko, O., Ocheretyanko, M. \& Kasyanchuk, S. (2016). The use of contact heat generators of the new generation for heat production. Eastern-European journal of enterprise technologies, 6/1 (84), 52-58. doi:10.15587/1729-4061.2016.86088

Ionkin, I. L., Ragutkin, A. V., Roslyakov, P. V., Supranov, V. M., Zaichenko, M. N. \& Luning, B. (2015). Effect of a Condensation Utilizer on the Operation of Steam and Hot Water Gas Fired Boilers. Thermal Engineering, 2015, Vol. 62, No.5, 352-358.

Kudinov, A. A. (2000). Energy Conservation in Heat Generating Installations. Ulyanovsk: UlGTU, (in Russian).

Izyumov, M. A. \& Supranov, V. M. (2010). Carrying out coordinated thermal calculations of a boiler and pulverized coal systems on the basis of adequate analytical models, Proc. of the 18th International Scientific Technical Conference "Information Tools and Technologies". Moscow: MEI, Vol. 3, 166-173.

Mel'nikov, D. A., Vereshchetin, V. A., Tugov, A. N. \& Sidorkin, V. T. (2014). The analytical model of a TP-101 boiler in the Boiler Designer computer program. The package of application computer programs for calculating thermal power equipment. Proc. of the International Scientific Practical Conference "Boiler Designer 2014". Moscow: Torus Press.

Pleshanov, K. A., Latish, V. Yu, \& Knyaz'kov, V. P. (2014). Investigating the startup of the Pk-85 boiler at the Novogor'kovskaya cogeneration station: The package of application computer programs for calculating thermal power equipment. Proc. of the International Scientific Practical Conference "Boiler Designer 2014". Moscow: Torus Press.

О. Т. Возняк, Ю. С. Юркевич, М. Є. Касинець, І. Є. Сухолова, О. М. Довбуш Національний університет "Львівська політехніка" Кафедра теплогазопостачання і вентиляції

\title{
КОНТАКТНО-ПОВЕРХНЕВИЙ ТЕПЛОУТИЛІЗАТОР
}

\author{
(ㄱ Возняк О. Т., Юркевич Ю. С., Касинець М. С., Сухолова І. С., Довбуи О. М., 2020
}

У промисловості застосовуються контактно-поверхневі теплообмінники. В цих апаратах реалізується глибоке охолодження продуктів спалювання (30-40 $\left.{ }^{\circ} \mathrm{C}\right)$. При розрахунку контактноповерхневих теплообмінників поверхневий коефіцієнт передачі повного тепла для насадкової камери $\epsilon$ найважливішим фактором, що визначає як контактну частину, так i зведений поверхневий теплообмінник. Цього досягають декількома методами. При цьому виникають труднощі 3 вибором найефективнішого методу, який би забезпечував високу точність розрахунку цієї величини, а також не був би надто складним. У цій статті запропонований метод розрахунку величини $\sigma$ для контактноповерхневих теплообмінників, який відповідає обидвом умовам, описаними вище. Як основний застосовують метод чисельного інтегрування, за яким можна обчислити значення $\sigma$ із найбільшою точністю. Значення $\sigma$ подається як функція чотирьох незалежних аргументів. Отримані результати подано у вигляді діаграми, яку апроксимовано за допомогою рівняння. Отже, можна стверджувати, що запропоновано ефективний метод розрахунку коефіцієнта передавання повної теплоти для насадкової камери в контактно-поверхневих теплообмінниках, які використовуються для загального та технологічного гарячого водопостачання.

Метою статті $є$ вибір найраціональніших схем складу обладнання утилізації тепла для використання тепла продуктів спалювання ендогазу та розроблення інженерного методу розрахунку цього обладнання. Отримані залежності доволі прості у використанні та дають хорошу узгодженість результатів. Запропоновано ефективний метод визначення коефіцієнта передавання повного тепла для насадкової камери в контактних теплообмінниках при будь-яких заданих вихідних значеннях у вказаному інтервалі, що дає змогу проводити розрахунки як графічно, так і аналітично.

Ключові слова: контактно-поверхневий теплоутилізатор, ендогаз, керамічні кільця Рашига, активна насадкова камера, коефіціснт передачі повного тепла, зрошувальна поверхня, теплообмінник. 